\title{
IWONA SOBIERAJ
}

PoliteCHNIKA ŚląSKA

SzKoŁA Wyższa IM. B. JAŃsKIEGo

EMAIL: IWONA.SOBIERAJ@POLSL.PL

\section{KOMPETENCJE MIĘDZYKULTUROWE JAKO KAPITAŁ NA RYNKU PRACY}

\section{Internacjonalizacja rynku pracy w społeczeństwie informacyjnym i globalnej gospodarce}

Powstawanie społeczeństwa informacyjnego jest procesem, który przenika niemal wszystkie sfery życia społecznego. Cechą tego społeczeństwa jest wykorzystywanie w komunikowaniu społecznym nowoczesnych technologii informatyczno-komunikacyjnych (TIK). Dzięki szybkiemu ich rozwojowi i coraz większej dostępności oraz dynamicznie rozrastającej się sieci Internetu społeczeństwo polskie zostaje włączone w przestrzeń globalnego społeczeństwa informacyjnego. Jednym $z$ efektów rozwoju środków i technik masowego przekazu oraz komunikacji cyfrowej jest wzrost liczebności i intensywności komunikacji społecznej w tym także, komunikacji międzykulturowej. Według badań CBOS-u z 2012 roku 56\% Polaków deklarowało, że ma w domu dostęp do Internetu i korzysta $\mathrm{z}$ niego co najmniej raz w tygodniu. Ten odsetek jest negatywnie skorelowany $\mathrm{z}$ wiekiem respondentów, co powoduje, że w grupie wiekowej 18 - 24 udział użytkowników Internetu sięga już 93\% [Felisiak 2012: 2].

Szybkość i niska cena komunikacji za pośrednictwem Internetu oraz innych nowoczesnych technologii stała się także okazją do rozwoju wielu przedsiębiorstw, dając im możliwość poszerzania kontaktów zagranicznych, zaistnienia na skalę ponadnarodową i zdobywania nowych rynków, niezależnie od wielkości firmy i kapitału ekonomicznego, który posiadają. Najważniejszym kapitałem w tym zakresie są przede wszystkim odpowiednie kompetencje pracowników i świadomość ich znaczenia wśród pracodawców. Badania zrealizowane przez Centrum Informacji Społeczno-Gospodarczej w 2010 roku w polskich przedsiębiorstwach wskazują wykorzystanie Internetu przez niemal 100\% firm dużych i średnich, ten udział był niższy tylko w mikroprzedsiębiorstwach (od 1 do 
9 osób), w których sięgał ponad 60\% [Raport: Internet 2010]. Wzrasta także odsetek Polaków, który znają języki obce. Według danych CBOS-u z 2009 roku prawie co drugi Polak (46\%) deklarował, że potrafi się porozumieć w języku obcym, w tym 32\% znała jeden język, 11\% dwa języki, a 3\% trzy i więcej. Do roku 2006 w badaniach CBOS-u największy odsetek Polaków (22\%) deklarował znajomość języka rosyjskiego, a w badaniu w 2009 największa część (24\%) zadeklarowała znajomość języka angielskiego, co piąty rosyjskiego, a co 12\% niemieckiego [Raport Polacy, 2009].

Można zatem przewidywać, że ogółem udział osób i przedsiębiorstw korzystających z Internetu będzie się nadal zwiększał zarówno poprzez wymianę pokoleń, jak też ze względu na wprowadzanie nowych technologii w szkołach i przedsiębiorstwach. Zarazem posiadanie kompetencji informacyjno-komunikacyjnych (Information Communication Technologies - ICT) stanie się podstawowym warunkiem zatrudnienia w większości organizacji. Wraz z rozwojem i upowszechnianiem się nowoczesnych technologii wzrastać będzie także potrzeba posiadania kompetencji międzykulturowych (Cross-Culture - CC), a ich wzajemna zależność będzie się nasilała, jak pokazuje rysunek 1. Dzięki ich wykorzystywaniu potencjalny rynek klientów może zostać poszerzony do skali globalnej, bez ponoszenia znaczących kosztów. Jednak sprawna komunikacja $\mathrm{z}$ klientami $\mathrm{z}$ innych kręgów kulturowych wymaga nie tylko umiejętnego stosowania tych technologii, oraz znajomości języków obcych. Do skutecznej, efektywnej komunikacji na globalnym rynku niezbędna jest także wiedza $\mathrm{z}$ zakresu komunikacji międzykulturowej. Potrzeba rozwoju tych obu rodzajów kompetencji jest ze sobą wzajemnie powiązana [Jaskuła, Korporowicz 2008: 83-105]. Stają się one wymogiem skutecznego działania, zarówno w odniesieniu do organizacji i jej pracowników, jak też prywatnego życia jednostek. Coraz częściej dostęp do informacji jest ograniczony przede wszystkim kompetencjami odbiorcy: umiejętnościami posługiwania się technologiami informacyjno-komunikacyjnymi oraz znajomością języków obcych. 


\section{Rysunek 1. Wzrost zależności pomiędzy rozwojem kompetencji} informacyjno-komunikacyjnych w zakresie (ICT) i rozwojem kompetencji międzykulturowych.
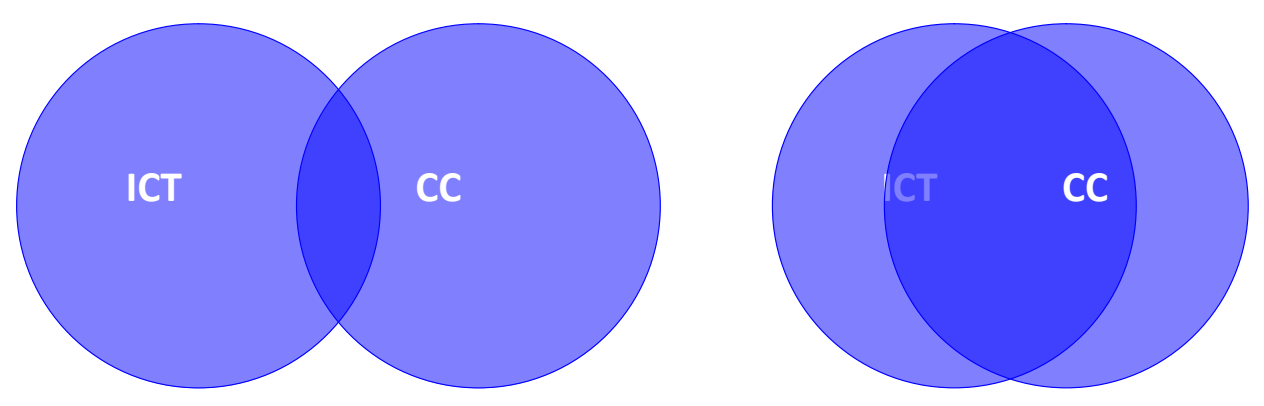

Źródło: opracowanie na podstawie: [Jaskuła, Korporowicz 2008: 83-105].

Potrzeba kompetencji międzykulturowych pojawia się wśród pracowników i pracodawców najczęściej w sytuacji współpracy gospodarczej z inwestorami zagranicznymi. W Polsce jest zarejestrowanych ponad 50000 firm z udziałem kapitału zagranicznego, a w zarządach spółek zasiada ponad 30000 obcokrajowców. Mamy do czynienia ze stale rosnącym rynkiem, gdyż od kilku już lat co roku rejestruje swoją działalność w Polsce ponad 2000 spółek z kapitałem zagranicznym [Centralny 2012].

Według Państwowej Agencji Inwestycji Zagranicznych od początku lat dziewięćdziesiątych wzrasta udział inwestycji zagranicznych pochodzących z Unii Europejskiej w Polsce. O ile w 1993 roku wartość inwestycji pochodzących z krajów Unii Europejskiej w Polsce wynosiła ok. 47\%, to w 2000 roku udział ten wzrósł do $67 \%$ wszystkich przedsięwzięć podjętych przez zagraniczne firmy, a w 2009 roku do 82\%. Wzrasta także ogółem ilość inwestycji zagranicznych w Polsce. Napływ bezpośrednich inwestycji zagranicznych (BIZ) do Polski w 2011 roku wyniósł 10904 mln EUR. Oznacza to wzrost w stosunku do poprzedniego roku o $63 \%{ }^{1}$.

Od kilkunastu lat na polskim rynku pracy pojawia się wzrastająca liczba cudzoziemców pracujących lub szukających zatrudnienia. Część z nich to osoby pracujące w szarej strefie, których liczebność trudno oszacować, a liczbę wydanych zezwoleń na pracę obcokrajowcom podaje co roku Ministerstwo Pracy i Polityki Socjalnej. W roku 2011 wydano w Polsce 40808 zezwoleń na pracę obcokrajowcom, co stanowiło o ponad $11 \%$ więcej niż rok wcześniej. Wśród nich dominują zezwolenia wydane dla obywateli Ukrainy (18669), Chin (5918),

1 http://www.paiz.gov.pl/polska_w_liczbach/inwestycje_zagraniczne. 
Wietnamu (2504), Białorusi (1725), Nepalu (1202), Turcji (1187), Indii (1055), Mołdowy (1017). Wśród wydanych zezwoleń 3305 dotyczyło stanowisk kierowniczych, doradców i ekspertów, natomiast największa część odnosiła się do robotników wykwalifikowanych (13304) i pracowników prac prostych (6491)².

Współpraca międzynarodowa i funkcjonowanie na globalnym rynku jest nadal domeną dużych organizacji, ale coraz więcej małych i średnich firm docenia możliwości w zakresie pozyskiwania nowych klientów, monitorowania rynku, współpracy z kontrahentami zagranicznymi itp. jakie daje Internet, czy chociażby udział Polski w Strefie Schengen. Nawet organizacje działające przede wszystkim na gruncie lokalnym czy regionalnym, nie są w stanie uniknąć procesów globalizacji i informatyzacji, które zmieniają otoczenie organizacji. Ponadto coraz więcej przedsiębiorstw rozszerza swój zakres działania, z regionalnego czy krajowego na międzynarodowy (co znacząco umożliwia Internet) i wówczas poszukiwanie i kontakt z kontrahentem zagranicznym, także wymagają posiadania określonych kompetencji międzykulturowych. Prowadzenie biznesu w sieci cieszy się w Polsce coraz większą popularnością. W ciągu ostatnich kilku lat w Polsce o 30-40\% rocznie zwiększa się liczba sklepów internetowych i na koniec 2010 roku przekroczyła 10 tysięcy, a obroty w handlu przez Internet przekroczyły 16 mld złotych ${ }^{3}$.

Peter Drucker, w swojej książce o zarządzaniu w XXI wieku uzasadniał, że efekty globalizacji są nie do uniknięcia dla współczesnych przedsiębiorstw, nawet jeśli dana organizacja nie wykracza zasięgiem swojej działalności poza rynek lokalny, „przedsiębiorcy muszą się liczyć ze skutkami globalnej konkurencji - nierzadko z krajów, których nie umieliby nawet wskazać na mapie, (...) zapewnienie konkurencyjności na skalę globalną winno być celem strategicznym każdej instytucji. Żadna organizacja, ani przedsiębiorstwo, ani uniwersytet, ani szpital, nie może liczyć na przetrwanie, ani na sukces, jeżeli nie jest w stanie sprostać standardom wyznaczonym przez liderów w swej branży, niezależnie ich jego lokalizacji”[Drucker 1999: 77, 141].

Korzystanie z technologii informatyczno-komunikacyjnych, przełamując bariery w postaci granic politycznych, czy odległości przestrzennej, umożliwia i ułatwia komunikację pomiędzy przedstawicielami różnych kultur. Staje się ona coraz powszechniejsza w życiu zawodowym i prywatnym. Nie oznacza to, jednak że technologie te przełamują bariery międzykulturowe. Wręcz przeciwnie, w sytuacji braku lub zmniejszania się znaczenia barier o innym charakterze, to różnice międzykulturowe nabierają istotnej wagi w funkcjonowaniu organizacji.

2 http://www.mpips.gov.pl/analizy-i-raporty/cudzoziemcy-pracujacy-w-polsce-statystyki/.

3 http://wyborcza.pl/1,76842,8925067,Wartosc_handlu_w_internecie_przekroczyla_16_mld_zlotych.html. 


\section{Kompetencje międzykulturowe w organizacji}

Do najważniejszych konsekwencji procesów globalizacji i modernizacji gospodarki dla organizacji, szczególnie przedsiębiorstw, można zaliczyć:

- zacieranie znaczenia granic państwowych w prowadzeniu działalności gospodarczej,

- globalizację rynków,

- nasilenie konkurencji międzynarodowej,

- spadek roli państwa narodowego,

- wzrost potęgi kooperacji globalnych,

- migracje pracownicze i dywersyfikacja siły roboczej,

- wzrost międzynarodowej współzależności przedsiębiorstw [Gregor, Stawiszyński 2002: 12-34].

To nowe środowisko prowadzenia działalności gospodarczej charakteryzuje: informatyzacja, wysoki poziom suwerenności klientów, sieciowość oraz kluczowa rola informacji i wiedzy. Istotnym zadaniem dla organizacji działającej $\mathrm{w}$ przestrzeni technologii informacyjno-komunikacyjnych będzie nabywanie umiejętności organizowania informacji, jej weryfikacji i selekcji. A informacje dotyczące otoczenia organizacji stają się jednym z najpoważniejszych wyzwań zarządzania. Analiza zmian społecznych związanych z rozwojem technologicznym i przemianami społeczno-politycznymi (np. wejście Polski do Schengen) pozwala sądzić, że zarówno liczba obszarów, w których niezbędne będą kompetencje międzykulturowe, jak i ich zakres będą stopniowo wzrastać. Coraz większa będzie też liczba osób, które będą musiały wykorzystywać te kompetencje w pracy zawodowej.

Środowisko zawodowe współczesnego pracownika coraz częściej wymaga akceptacji i dostosowania się do kontaktu z przedstawicielami innych kultur, a także gotowości do pracy w warunkach transkulturowych. Warunki transkulturowości najczęściej pojawiają się w przedsiębiorstwach wysokich technologii informacyjno-komunikacyjnych czy korporacjach międzynarodowych. W nich kontakty zawodowe pracowników dotyczą coraz częściej nie tylko jednej innej kultury, ale wymagają współpracy z przedstawicielami wielu kultur jednocześnie i mogą się zmieniać z dnia na dzień, czy z godziny na godzinę. Pracownicy, a szczególnie menedżerowie, muszą się przystosować do współpracy i wchodzenia w interakcje w sytuacji niepewności bądź nieznajomości kultury partnera. Dzisiaj jednym z pól takiego współdziałania na szerszą skalę są organizacje i korporacje międzynarodowe, ale także coraz częściej małe i średnie organizacje, które w różny sposób współpracują z partnerami ponad granicami 
państwowymi. Niezbędną podstawą takich interakcji są własna świadomość kulturowa oraz kompetencje międzykulturowe.

W gospodarce opartej głównie na usługach, kompetencje międzykulturowe mają istotne znaczenie wśród kompetencji zawodowych. Na kompetencje te składa się zarówno określony zasób wiedzy, jak też zdolność do jej praktycznego i elastycznego stosowania oraz motywacja do jej wykorzystywania. Właśnie motywacja staje się często decydującym elementem zaistnienia kompetencji międzykulturowych. Motywacja wewnętrzna wyrażająca się w określonych postawach wobec kontaktów międzykulturowych jest zależna od osobowości, doświadczeń życiowych, wyznawanych wartości. Pozytywna postawa wobec kontaktu międzykulturowego wymaga komunikatywności, zdolności do transgresji, otwartości wobec zmian i akceptacji mobilności, zarówno w odniesieniu do siebie jak i do innych. Postawa ta, w sytuacjach zawodowych, może być wzmacniana również motywacją zewnętrzną, poprzez odpowiedni system motywacyjny, jednak jej podstawę stanowi wewnętrzna motywacja oraz wyznawane wartości. Odpowiednie postawy wobec nabywania kompetencji międzykulturowych stanowią także niezmiernie istotny punkt wyjściowy do szkolenia i doskonalenia tych kompetencji [Storti 2009: 272 - 285]. Postawy sprzyjające rozwijaniu kompetencji międzykulturowych to przede wszystkim gotowość i chęć do wchodzenia w interakcje z innymi ludźmi, pozytywne nastawienie do doświadczania odmienności, mobilność w przestrzeni realnej i wirtualnej, oraz otwartość na zmiany (rysunek 2).

Rysunek 2. Postawy jako element kompetencji międzykulturowych.

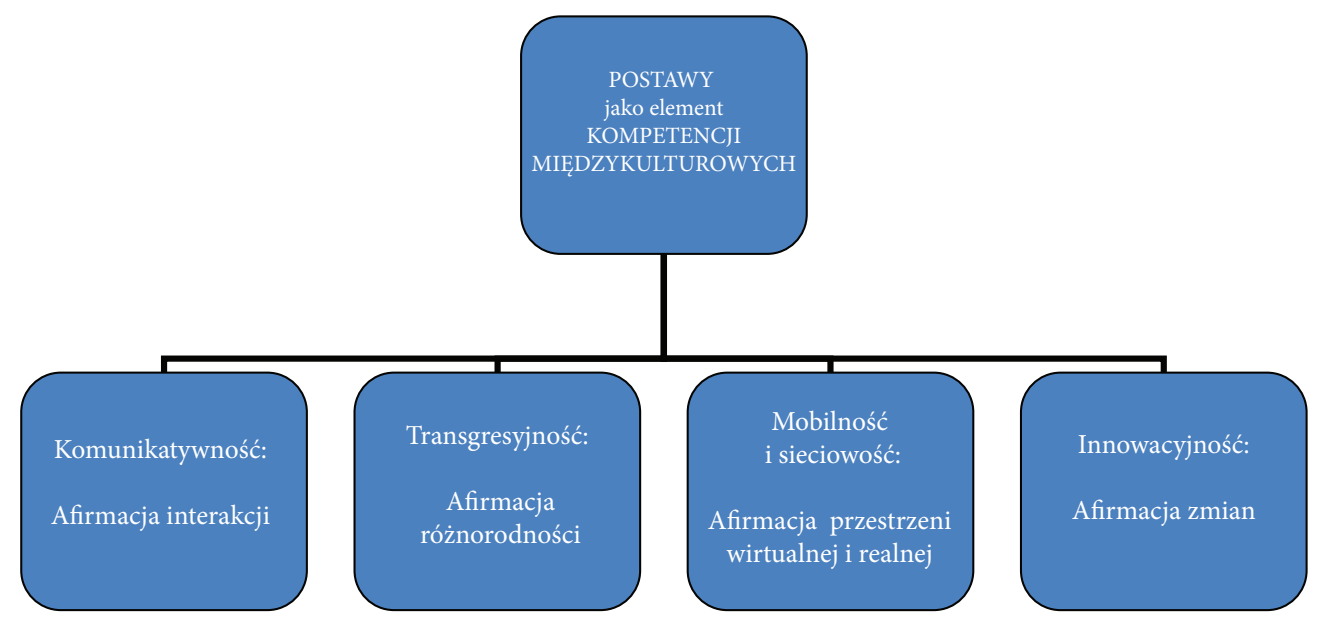

Źródło: opracowanie własne. 
Wielokulturowość w odniesieniu do organizacji oznacza pogląd że „istnieje wiele odmiennych środowisk i czynników kulturowych o dużym znaczeniu dla organizacji, oraz że ludzie wywodzący się z tych rozmaitych środowisk mogą współistnieć i odnosić sukces w organizacji” [Stoner i in. 2001, s. 179]. Nie pojawia się ona jednak automatycznie wraz ze zróżnicowaniem kulturowym w obrębie organizacji. Wymaga przyjęcia określonych zasad współdziałania, obejmujących zarówno określony margines swobody działania jak i pewne wspólne wszystkim członkom organizacji reguły. Zarówno Geert Hofstede, jak też inni badacze (jak na przykład Edward Hall i Alfons Trompenaars) wskazywali na różne wymiary kultury, w których uwidaczniały się istotne różnice kulturowe. Wymiary te to między innymi:

- kultury wysokiego kontekstu i kultury niskiego kontekstu,

- postawa wobec władzy,

- koncepcja jednostki (relacja jednostka - społeczeństwo wyrażająca się $\mathrm{w}$ indywidualizmie lub kolektywizmie, oraz koncepcja męskości i kobiecości),

- sposoby rozwiązywania konfliktów (kwestia ukazywania uczuć i kontroli agresji; unikanie niepewności),

- orientacja czasowa (długoterminowa i krótkoterminowa; czas linearny, elastyczny, cykliczny), [Reynolds, Valentine 2009: 20-26].

Jak podkreślał Geert Hofstede: „Właściwa ocena różnic kulturowych jest możliwa tylko wtedy, gdy zamiast stosowania własnych norm w odniesieniu do innych jednostek i grup społecznych, przyjrzymy się dokładnie istocie różnic, ich źródłom i konsekwencjom" [Hofstede, Hofstede 2007: 19]. Równie interesującym studium z zakresu psychologii kulturowej jest książka Richarda E. Nisbetta, w której podejmuje się wyjaśnienia istoty różnic w percepcji pomiędzy przedstawicielami kultur Wschodu i Zachodu. Wskazał on na wiele eksperymentów, w których wykazano głębokie różnice psychiczne i kulturowe obejmujące relacje społeczne, poglądy na naturę świata i charakterystyczne procesy myślowe, jednak ukazał również, że możliwa jest zmiana sposobów percepcji i występuje ona stosunkowo często u osób dwukulturowych [Nisbet 2009].

Skutki istnienia różnic kulturowych pomiędzy ludźmi, w szczególny sposób mogą się ujawniać w sytuacji pracy, gdy współpracownicy, klienci muszą ze sobą podjąć współpracę, aby działać efektywnie. Sytuacja wielokulturowości w organizacji może mieć różny zakres, a także charakter stopniowalny. W organizacji możemy mieć do czynienia z dwoma typami sytuacji, z których wynika potrzeba kompetencji międzykulturowych pracowników:

- zróżnicowanie odnoszące się do otoczenia organizacji (wielokulturowe otoczenie organizacji, bądź działanie o zasięgu ponadnarodowym), 
- zróżnicowanie odnoszące się do samej organizacji (wewnątrz organizacji istnieje zróżnicowane wśród pracowników, lub organizacja stanowi filię, oddział większej organizacji o zasięgu ponadnarodowym).

Jeżeli skrzyżujemy te dwa typy otrzymamy cztery stopnie, według których można hipotetycznie określić potrzebę kompetencji międzykulturowych w organizacji (tabela 1).

Tabela 1. Potrzeba kompetencji międzykulturowych w organizacji

\begin{tabular}{|l|c|c|}
\hline \multicolumn{1}{|c|}{ Wyszczególnienie } & $\begin{array}{l}\text { Niskie zróżnicowanie kulturo- } \\
\text { we wewnątrz organizacji }\end{array}$ & $\begin{array}{l}\text { Wysokie zróżnicowanie kultu- } \\
\text { rowe wewnątrz organizacji }\end{array}$ \\
\hline $\begin{array}{l}\text { Otoczenie organizacji } \\
\text { jednokulturowe, zasięg } \\
\text { działania regionalny, lub } \\
\text { krajowy }\end{array}$ & 1 & 2 \\
\hline $\begin{array}{l}\text { Otoczenie organizacji wielo- } \\
\text { kulturowe, bądź zasięg dzia- } \\
\text { łania ponadnarodowy }\end{array}$ & 3 & 4 \\
\hline
\end{tabular}

Źródło: opracowanie własne.

W przypadku czwartego typu potrzeba kompetencji międzykulturowych będzie hipotetycznie najwyższa. Będzie ona wynikała ze zróżnicowania wewnątrz organizacji, a więc będzie wpływała na powstanie takiej kultury organizacji, która powinna stwarzać płaszczyznę współpracy i porozumienia wśród pracowników. Będzie także wymogiem istnienia organizacji w wielokulturowym otoczeniu i jej dostępu do rynku oraz konsumentów/klientów. Kompetencje międzykulturowe będą niezbędne wszystkim pracownikom takiej organizacji, mogą dotyczyć wielu krajów, a ich zakres może być bardzo szeroki - zarówno dotyczyć spraw zawodowych, jak też innych na przykład towarzyskich/ osobistych.

W przypadku trzeciego typu organizacji, która jest wewnętrznie jednorodna, działa natomiast w zróżnicowanym kulturowo otoczeniu, kompetencje międzykulturowe będą istotne, ale mogą dotyczyć tylko niektórych pracowników (np. odpowiedzialnych za kontakty z klientami lub kontrahentami zagranicznymi), mogą także być zdominowane przez sprawy zawodowe i odnosić się przede wszystkim do tego zakresu wiedzy.

W przypadku drugiego typu organizacji, która jest wewnętrznie zróżnicowana kulturowo, kompetencje międzykulturowe są istotne dla wszystkich pra- 
cowników, jednak mogą się rozwinąć w ograniczonym zakresie. Jest to zależne od poziomu i siły kultury organizacji i tego na ile wymusza ona na pracownikach określone standardy zachowań zgodne nie tyle $\mathrm{z}$ ich własną kulturą, co z kulturą organizacji. W przypadku słabej kultury organizacji, kompetencje międzykulturowe będą prawdopodobnie bardziej rozwinięte, niż w przypadku silnej kultury organizacji, która narzuci wszystkim swoim członkom ujednolicone reguły zachowania.

W przypadku organizacji pierwszego typu potrzeba kompetencji międzykulturowych będzie hipotetycznie najniższa. Jednak kompetencje międzykulturowe są potrzebne nie tylko w sytuacji organizacji wielokulturowej lub w sytuacji wielokulturowego otoczenia. Ekonomiści podkreślają, że w zglobalizowanej gospodarce, istnieje konieczność stałego odnoszenia i porównywania się do najlepszych $\mathrm{z}$ danej branży przedsiębiorstw jest to tzw. benchmarking.

Rozwój teorii zarządzania od drugiej połowy XX wieku obejmował coraz silniej problematykę pluralizmu i wielokulturowości, zarówno jako właściwości nowego otoczenia globalnego i lokalnego, w którym działają organizacje, jak też jako pewną zmianę w samych organizacjach, dotyczącą składu pracowników, ich praw oraz radzenia sobie organizacji z pluralizmem kulturowym w jej obrębie.

Rozwój tych koncepcji zarządzania można przedstawić w trzech stadiach:

- polityki równych szans,

- doceniania różnorodności,

- zarządzania różnorodnością [Waszczak 2009: 79-80].

W pierwszym z tych stadiów pracodawcy skupiali się na działaniach, dzięki którym nie tylko stwarzane były równe szanse dostępu do miejsc pracy, ale także zwracano uwagę na konieczność zwiększenia dostępu do wyższych stanowisk dla osób z mniejszości. Drugie stadium - docenianie różnorodności w organizacji - jest ruchem mającym na celu zwiększanie świadomości, rozumienia i akceptacji różnic wśród pracowników między innymi poprzez zdywersyfikowaną siłę roboczą. Cele tych działań mają przede wszystkim charakter utylitarny, zmierzający do tego, aby wykorzystać potencjał różnorodności do zdobywania nowych rynków i pozyskiwania nowych klientów. Trzecie stadium - zarządzanie różnorodnością - jest podejściem, w którym różnorodność w organizacji jest postrzegana jako źródło przewagi konkurencyjnej oraz również jako wartość autoteliczna. W zarządzaniu różnorodnością zwraca się uwagę zarówno na korzyści, jakie z niej wynikają, jak też na możliwe trudności i konflikty. Jednak w tym podejściu silny akcent kładzie się na wytworzenie odpowiedniej kultury organizacyjnej, wspierającej wielokulturowość organizacji. Idea zarządzania różnorodnością narodziła się w latach osiemdziesiątych 
XX wieku w Stanach Zjednoczonych i Kanadzie i wkrótce zaczęła przyjmować się w Wielkiej Brytanii i innych krajach Europy Zachodniej [ibidem: 79-83].

Wielokulturowość w organizacji może odnosić się nie tylko do czynników kultury narodowej czy etnicznej, ale także do takich elementów jak wyznanie, płeć, rasa, sprawność fizyczna. Taylor Cox [2001: 79-83] z Uniwersytetu w Michigan wysunął sześć argumentów, przemawiających za tezą, że kierowanie różnorodnością kulturową może zwiększyć efektywność organizacji:

- argument kosztowy - w miarę dywersyfikacji organizacji koszty nieudolnego integrowania pracowników będą wzrastać.

- $\quad$ argument dotyczący pozyskiwania zasobów - organizację będące najsprawniejsze w zarządzaniu zróżnicowanym personelem będą także najskuteczniej rywalizować o siłę roboczą grup mniejszościowych, które w sytuacji kurczącej się siły roboczej, mogą stanowić istotny potencjał.

- argument rynkowy - w organizacjach transnarodowych wyczucia i wrażliwość kulturowa, wnoszone przez członków, pochodzących z innych krajów, mogą skutecznie zwiększać skuteczność oddziaływań marketingowych.

- $\quad$ argument dotyczący twórczości - różnorodny punkt wiedzenia i większy nacisk na samodzielność i różnorodność, cechujący zarządzanie w warunkach wielokulturowości, sprzyja wyższemu poziomowi twórczości.

- rozwiązywania problemów - różnorodność składu grup decyzyjnych i grup rozwiązujących problemy potencjalnie prowadzi do skuteczniejszych decyzji dzięki gruntowniejszej krytycznej analizie poszczególnych rozwiązań.

- $\quad$ argument dotyczący elastyczności systemu - jedną z konsekwencji wielokulturowego modelu kierowania różnorodnością jest to, że system stanie się w mniejszym stopniu zdeterminowany, mniej unormowany, a bardziej płynny i elastyczny w działaniu.

O tym, jak istotne mogą być w najbliższej przyszłości kompetencje międzykulturowe na polskim rynku pracy wskazywać mogą ostatnie analizy i badania w zakresie gospodarki polskiej. Z badań Atrakcyjności Inwestycyjnej Europy przeprowadzonych przez firmę doradczą Ernst \& Young wynika, że Polska zajęła trzecie miejsce pod względem liczby miejsc pracy stworzonych dzięki bezpośrednim inwestycjom zagranicznym w 2010 roku. W 2010 roku inwestorzy zagraniczni stworzyli w Polsce 12,4 tysięcy miejsc pracy - 40\% więcej niż w roku 2009. Największymi inwestorami są w Polsce firmy amerykańskie, które w 2010 roku stworzyły poprzez BIZ ponad 3,8 tysięcy miejsc pracy [Badanie 2012]. 
Z kolei wyniki Ogólnopolskiego Badania Wynagrodzeń przeprowadzonego przez Sedlak \& Sedlak potwierdzają związek pomiędzy biegłą znajomością języka obcego, a średnią płacą, która w odniesieniu do osób nie znających żadnego języka obcego wynosiła 3200 zł. brutto, natomiast średnie zarobki osób znających biegle jeden język obcy wynosiły 4500 zł. Najwyższe średnie zarobki osiągały osoby znające biegle język angielski [Ogólnopolskie 2012].

Potwierdzają to także badania zrealizowane wśród pracodawców i pracowników województwa śląskiego w 2011 roku, według których ponad 75\% pracodawców oraz ponad 79\% pracowników uznała, że znaczenie kompetencji międzykulturowych w ich przedsiębiorstwach jest obecnie duże lub bardzo duże, a większość badanych uważała że będzie ono nadal wzrastać w przyszłości [Sobieraj 2012: 73-85].

Kompetencje międzykulturowe stanowią niewątpliwie coraz ważniejszy element gospodarki i rynku pracy w Polsce, choć polskie przedsiębiorstwa stoją na początku procesu zmian jakie przechodzą przedsiębiorstwa w Europie Zachodniej czy Stanach Zjednoczonych w kontekście zarządzania różnorodnością. Niemniej, także w Polsce, proces ten jest nieuniknioną konsekwencją między innymi globalizacji, modernizacji, migracji oraz rozwoju Information Communication Technologies.

\section{Bibliografia}

Cox T. [2001] Cultural Diversity in Organization. Theory, Research and Practice, Ann Arbor Drucker P. [1999] Zarzadzanie w XXI wieku - wyzwania, Klasyka Biznesu

Gregor B., Stawiszyński M. [2002] e-Commerce, Bydgoszcz

Hofstede G., Hofstede G.J. [2007] Kultury i organizacje, Warszawa

Jaskuła S., Korporowicz L. [2008] Wychowanie do informacji: wyzwania i nadzieje, „Pedagogika Społeczna" R. VII, nr 1(27)

Nisbett R.E. [2009] Geografia myślenia. Dlaczego ludzie Wschodu i Zachodu myśla inaczej?, Sopot

Raport Polacy o swoich wyjazdach zagranicznych i znajomości języków obcych [2009] CBOS$\mathrm{BS} / 111$, Warszawa

Reynolds S., Valentine D. [2009] Komunikacja międzykulturowa, Warszawa

Sobieraj I. (red.), [2012] Kompetencje informacyjno-komunikacyjne i międzykulturowe w gospodarce. Od adaptacji do innowacji, Warszawa

Storti C. [2009] Passing It On: Intercultural Competence in the Traning Arena, [w:] D.K. Deardorf (red.), Intercultural Competence, SAGE

Stoner J.A.F., Freeman R.E., Gilbert R.D. jr [2001] Kierowanie, Warszawa 
Waszczak S. [2009] Postawy wobec różnorodności - uwarunkowania, próba typologii, implikacje, [w:] M. Juchnowicz (red.) Kulturowe uwarunkowania zarządzania kapitałem ludzkim, Kraków

\section{Dokumenty elektroniczne:}

Badanie Atrakcyjności Inwestycyjnej Europy, http://www.paiz.gov.pl/20110615/raport_ernst_ young [15.03.2013]

Baranowski Sz. [2011], Wartość w handlu w Internecie przekroczyła 16 mld. zł. http://wyborcza.pl/1,76842,8925067,Wartosc_handlu_w_internecie_przekroczyla_16_mld_zlotych. html, [20.08.2012]

Centralny Ośrodek Informacji Gospodarczej, http://coig.com.pl/index.php?lang=pl\&main_ $\mathrm{id}=7 \&$ main=Inwestorzy\%20zagraniczni\%20w\%20\%20Polsce, [20.08.2012]

Felisiak M. [2012], Raport „Korzystanie z Internetu”, CBOS BS 81/2012: http://www.cbos.pl/ SPISKOM.POL/2012/K_081_12.PDF, [20.08.2012]

Ogólnopolskie Badanie Wynagrodzeń, Sedlak\&Sedlak: http://www.wynagrodzenia.pl/dla_ prasy_1.php/wpis.74/ [12.02.2012]

Polska Agencja Informacji i Inwestycji Zagranicznych: http://www.paiz.gov.pl/20110615/raport_ernst_young, [12.02.2012]

Raport: Internet w polskich firmach [2010], http://www.eu-go.gov.pl/pl/informacje-dlakonsumenta/176-internet-w-polskich-firmach/, [12.02.2012]

Raport Ministerstwa Pracy i Polityki Socjalnej: Cudzoziemcy pracujący w Polsce, http:// www.mpips.gov.pl/analizy-i-raporty/cudzoziemcy-pracujacy-w-polsce-statystyki/, [20.08.2012]

Rocznik Statystyczny Handlu Zagranicznego, GUS [2010], www.stat.gov.pl/cps/rde/xbcr/gus/ PUBL_rs_rocz_stat_hanl_zagr_2010.pdf [15.03.2013] 


\section{SUMMARY}

\section{Intercultural competence as a capital in the labour market}

In the case of dynamic changes in the labour market and high unemployment, the question of which abilities give a chance of finding a job, or maintaining it is particularly important. It concerns the employees as well as employers who are seeking suitable employees and they must know what skills are needed to develop their business. Adapting workers and businesses to the requirements of a changing economy becomes a condition of their survival and development. And these changes are related primarily to the processes of transformation and economic modernization, and globalization and internationalization of the economy. In this article factors influencing the increasing importance of intercultural competence in the Polish labour market and the implications of this change for employers and employees, that may occur in different types of organizations have been discussed. Intercultural competencies have been defined as knowledge, skills and attitudes to allow for establishing and maintaining positive personal contacts and professional relationships and effective communication with members of other cultures. The first part of this article concerns the factors of internationalization of the Polish labour market. The second one shows the consequences of this phenomenon for organizations: businesses, business environments and others.

\section{Keywords:}

intercultural competencies, market internationalization, multiculturalism, labour, sociology of organizations 